\title{
Betur má ef duga skal
}

\section{Vilhjálmur Ari Arason}

bráđamóttöku Landspítala

vaa@itn.is

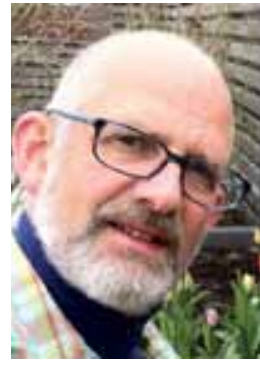

Ónauðsynleg sýklalyfjanotkun er talin eiga stærstu sök í hratt vaxandi sýklalyfjaónæmi meðal helstu sýkingavalda mannsins. Рað er pví mat Alpjóðaheilbrigðisstofnunarinnar (WHO) að eitt af veigamestu verkefnum heilbrigðiskerfa heims sé að taka á pessum vanda. ${ }^{1}$ Notkun sýklalyfja í landbúnaði hefur síðan víða verið enn meiri en meðal manna. ${ }^{2}$ Tengsl milli sýklalyfjanotkunar og próunar ónæmis er vel pekkt, meðal annars með stökkbreytingum í erfðaefni baktería sem flust geta á milli tegunda og síðan útbreiðslu ónæmu stofnanna í pjóðfélaginu og á sjúkrahúsum á kostnað peirra næmu. Auðvelt hefur verið að sjá slík tengsl hér á landi milli eins algengasta sýkingarvaldsins, lungnabólgubakteríunnar svokölluðu, Streptococcus pneumoniae, sem gjarna finnst í nefkoki barna og getur valdið erfiðum sýkingum, einkum miðeyrnabólgu, kinnholubólgusýkingu og lungnabólgu. ${ }^{3}$ Kraftaverkalyfið penisilín sem talið er hafa bjargað fleiri mannslífum en nokkurt annað lyf og lengt meðalaldur í hinum vestræna heimi um meira en áratug, fékk pví miður ekki lengi griðstað í aldingarðinum Eden eftir að pað kom fyrst á markað fyrir rúmri hálfri öld. Sama sagan hefur síðan verið með flest önnur sýklalyf síðar og bakteríurnar orðið ónæmar fyrir peim og engin ný öflug lyf í augsýn. ${ }^{1}$ Eins og segja má reyndar um flestar lífverur, aðlagast bakteríuflóran pannig breyttum umhverfisaðstæðum hverju sinni. Рað er hins vegar á valdi lækna að sjá til pess að spilla flórunni ekki um of, okkur öllum í hag síðar.

Síðastliðna tvo áratugi hefur verið markvist unnið að pví hjá heilbrigðisyfirvöldum að draga úr óparfa ávísunum lækna á sýklalyf, einkum til barna með væg sýkingareinkenni. ${ }^{3}$ Í slíkum tilfellum er að jafnaði um veirusýkingar að ræða par sem sýklalyf koma að engu gagni eða pá vægar bakteríusýkingar sem líkaminn ræður í flestum tilvikum vel við. ${ }^{3}$ Pá er frekar hvatt til nánara eftirlits með sýkingareinkennum. Pannig hefur verið hægt að komast hjá sýklalyfjagjöf í meirihluta tilvika víða erlendis, einkum meðal barna. Sýnt hefur verið fram á góðan árangur af slíkum aðgerðum hér á landi á ákveðnum landsvæðum yfir ákveðin tímabil. Í klínískum leiðbeiningum Embættis landlæknis er nánar tiltekið um ábendingar fyrir sýklalyfjameðferð varðandi flestar algengustu sýkingarnar og fyrsta val lyfja. Par er vert að hafa í huga að enn eitt vandamálið hér á landi snýr einmitt að mikilli notkun breiðvirkra sýklalyfja á kostnað peirra pröngvirku.

Í síðasta hefti Læknablaðsins var birt grein eftir Önnu Mjöll Matthíasdóttur og félaga um breytt viðhorf til sýklalyfjaávísana hjá íslenskum heimilis- og heilsugæslulæknum með tilliti til umræðunnar. ${ }^{4}$ Í niðurstöðum rannsóknarinnar má glöggt sjá að ákveðin vitundarvakning hefur átt sér stað um aukna árvekni gegn ónauðsynlegri sýklalyfjameðferð. Spyrja má pó af hverju svona illa hafi gengið að draga úr mikilli og oft óparfri sýklalyfjanotkun hér á landi, á sama tíma og betur gengur hjá nágrannapjóðunum. Rannsóknir hafa sýnt að ávísunarvenjur lækna á sýklalyf ráðast af mörgum páttum öðrum en bara pekkingu læknis. Mikið vaktaálag, styttri viðtalstímar, væntingar sjúklings, lyfjaauglýsingar og vinnubrögð kollega í sömu aðstæðum geta líka haft mikil áhrif á ákvörðun um lyfjaávísun. ${ }^{5}$ Víða er undirmönnun í heilsugæslunni og vaktaálag pví mikið hér á landi, ekki síst á sjálfu höfuðborgarsvæðinu par sem sýklalyfjanotkunin er mest.

Sem betur fer er sýklalyfjaónæmi alvarlegustu sýkingarvaldanna enn lítið hér á landi miðað við víða erlendis, enda landið frekar einangrað, pjóðin fámenn og almennt heilbrigði gott. Engu að síður höfum við á síðustu áratugum fengið faraldra fjölónæmra pneumókokka sem náð hafa bólfestu í nefkoki hjá allt að 20\% barna, sem rekja má að hluta til mikillar sýklalyfjanotkunar peirra. ${ }^{3}$ Sýkingum fjölónæmra sýkingarvalda á sjúkrahúsum má einnig halda niðri með réttri notkun sýklalyfja og áherslu á hreinlæti og góðar smitsjúkdómavarnir. Petta er varnarbarátta par sem sífellt meira hefur samt orðið að láta undan. Ákveðnir algengir sýkingarvaldar á sjúkrahúsum erlendis eru hins vegar í sumum tilvikum orðnir ónæmir fyrir öllum hugsanlegum sýklalyfjum sem til eru og pví aðeins tímaspursmál hvenær slíkar sýkingar koma einnig upp hér á landi. Fjölgun ferðamanna, aukinn innflutningur á hverskonar hrávöru og tíð ferðalög landans erlendis geta flýtt pessari próun, bæði í samfélaginu og á sjúkrahúsunum. Nýjar bólusetningar gegn algengum sýklalyfjaónæmum bakteríustofnum í pjóðfélaginu, til dæmis pneumókokkum, ættu líka að geta dregið að minnsta kosti tímabundið úr tíðni algengustu sýkinganna sem peir valda og skapað okkur betra tækifæri til aðhaldsaðgerða. Рað er pó alltaf á ábyrgð læknanna sjálfra að nota sýklalyfin af meiri kostgæfni en verið hefur og sporna pannig gegn próuninni. Vandi lækna er pví sá að bera hag sjúklingsins í huga, jafnhliða pví að viðhalda samfélagslegri ábyrgð á pví sem kann að próast á morgun.

\section{Heimildir}

1. Center for Disease dynamics, economics and policy 2015. The state of the world's antibiotics 2015. CDDEP. Washington DC.

2. Sýklalyfjanotkun og sýklalyfjanæmi baktería í mönnum og dýrum á Íslandi 2013. Landspítali, sóttvarnalæknir, Lyfjastofnun, Matvælastofnun, 2014.

3. Arason VA, Sigurdsson JA. The problems of antibiotic overuse. Scand J Prim Health Care 2010; 28: 65-6.

4. Matthíasdóttir AM, Guðnason $\mathrm{P}$, Halldórsson M, Haraldsson Á, Kristinsson KG. Breytt viðhorf til sýklalyfjaávísana hjá íslenskum heimilis- og heilsugæslulæknum. Leknablaðið 2016; 102: 27-31.

5. Petursson P. GPs' reasons for "non-pharmacological" prescribing of antibiotics: A phenomenological study. Scand J Prim Health Care 2005; 23: 120-5.

Icelandic doctors can do much better - to halt unnecessary antimicrobial prescriptions

Vilhjálmur Ari Arason, MD, GP, PhD Emergency department, Landspítali - The National University Hospital of Iceland 